\title{
A NEW HUNGARIAN OCCURRENCE OF ENTODON CONCINNUS (DE NOT.) PARIS FROM WESTERN HUNGARY
}

\author{
Gabriella Fintha \& Péter Szú́cs*
}
Eszterházy Károly University, Institute of Biology, Department of Botany and Plant Physiology, H-3300 Eger, Leányka str. 6, Hungary;
*E-mail: szucs.peter@uni-eszterhazy.hu

Hungary, Vas County, Apátistvánfalva village, Fő street 51, parking of Apát Hotel, on the top of embankment, in mown lawn, on soil (leg. Gabriella Fintha, 09.11.2019.; det. Péter Szűcs \& Gabriella Fintha [EGR]; conf. Peter Erzberger) alt. 290 m, N46.893611, $\mathrm{E}^{\circ}$ 16.260833; associated bryophtyes: Climacium dendroides, Hylocomium splendens, Pseudoscleropodium purum, Rhytidiadelphus squarrosus, $R$. triquetrus.

The Entodon concinnus has circumpolar distribution, and occurs basically on alkaline, calcareous, arid, grassy areas (Dierßen 2001). This taxon is common in the western parts of Europe and is not endangered (Hodgetts et al. 2019). In Hungary for a long time only one occurrence was known from the Botanical Garden of Vácrátót (Pócs et al. 2008), therefore, according to the Hungarian Red List (Papp et al. 2010) it is critically endangered in our country. In recent years, new populations of the taxon were detected (Király et al. 2019, Fintha et al. in press) from calcareous sandy soil, which are geographically close to the Vácrátót locality (Figure 1). Considering bryophyte species the Őrség region is well-explored (Pócs et al. 1958, Papp and Rajczy 1996, Ódor et al. 2002, Szűcs 2009), data of E. concinnus is new for this, and with greater outlook, for the whole Transdanubian region. The new data presented here support the hypothesis that the distribution of the taxon in Hungary is not limited to the calcareous sandy soils of the Pest sedimentary plain. It can occur throughout the country, even on acidic grounds, in regions with climatic conditions appropriate to the species' requirements. 


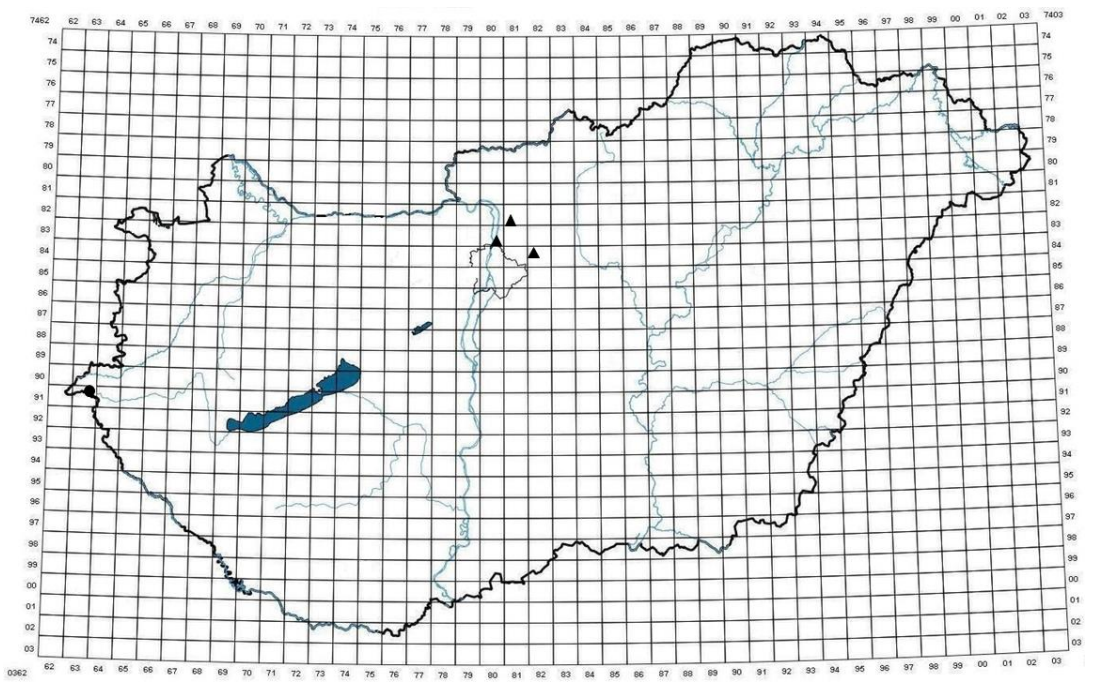

Figure 1. The distribution map of Entodon concinnus in Hungary; • new occurrence, $\boldsymbol{\Delta}$ published and known occurrences (based on Pócs et al. 2008; Király et al. 2019, Fintha et al. in press).

Acknowledgement - The second author's research was supported by the grant EFOP-3.6.1-16-2016-00001 ("Complex improvement of research capacities and services at Eszterházy Károly University"). The authors would like to express their gratitude to Erika Pénzes-Kónya and Tamás Pócs for their useful comments.

\section{REFERENCES}

DIERßEN, K. (2001). Distribution, ecological amplitude and phytosociological characterization of European bryophytes. Bryophytorum Bibliotheca 56: 1289.

Fintha, G., SzÛ́cs, P. \& ERzBerger, P. (in press). A gödi Huzella Kert mohaflórája. (The bryophyte flora of Huzella garden in Göd town (Pest county, Hungary)). Botanikai Közlemények 107.

Hodgetts, N., CÁlix, M., Englefield, E., Fettes, N., García Criado, M., Patin, L., Nieto, A., Bergamini, A., Bisang, I., Baisheva, E., Campisi, P., Cogoni, A., Hallingbäck, T.,Konstantinova, N., Lockhart, N., SAbovljevic, M., Schnyder, N., Schröck, C., Sérgio, C., Sim Sim, M., Vrba, J., Ferreira, C.C., Afonina, O., Blockeel, T., Blom, H., Caspari, S., Gabriel, R., Garcia, C., Garilleti, R., GonzÁlez Mancebo, J., GoldberG, I., Hedenäs, L., Holyoak, D., Hugonnot, V., Huttunen, S., Ignatov, M., Ignatova, E., Infante, M., JuUtinen, R., Kiebacher, T., KöCKinger, H., KuČERA, J., LÖnnell, N., LÜth, M., Martins, A., Maslovsky, O., Papp, B., Porley, R., Rothero, G., Söderström, L., ŞTefănuț, S., Syrjänen, K., Untereiner, A., VÁŇA, J. I, VAnderpoorten, A., Vellak, K., Aleffi, M., Bates, J., Bell, N., Brugués, M., Cronberg, N., Denyer, J., Duckett, J., During, H.J., Enroth, J., Fedosov, V., FlatberG, K.-I., Ganeva, A., Gorski, P., Gunnarsson, U., Hassel, K., Hespanhol, H., Hill, M., Hodd, R., Hylander, K., 
Ingerpuu, N., LaAka-LindberG, S., Lara, F., Mazimpaka, V., Mežaka, A., MÜller, F., Orgaz, J.D., Patiño, J., Pilkington, S., Puche, F., Ros, R.M., Rumsey, F., SegarraMoragues, J.G., Seneca, A., Stebel, A., Virtanen, R., Weibull, H., Wilbraham, J. \& ŻARnowiec, J. (2019). A miniature world in decline: European Red List of Mosses, Liverworts and Hornworts. IUCN, Belgium, $87 \mathrm{pp}$.

https://doi.org/10.2305/IUCN.CH.2019.ERL.2.en

Király, G., Baráth, K., Bauer, N., Erzberger, P., Papp, B., Szúcs, P., Veres, Sz. \& Barina, Z. (2019). Taxonomical and chorological notes 8 (85-93). Studia botanica hungarica 50(1): 241-252.

https://doi.org/10.17110/StudBot.2019.50.1.241

ÓDOR, P., SzuRDoKI, E. \& TóTH, Z. (2002). Az Őrség és a Vendvidék főbb élőhelyeinek mohavegetációja és flórája. Kanitzia 10: 15-60.

PAPP, B. \& RAJCZY, M. (1996). Az Őrség mohaflórája, a Magyar Természettudományi Múzeum Növénytára Mohaherbáriuma alapján. In: VIG, K. (ed.): Az Őrségi Tájvédelmi Körzet Természeti Képe II. Savaria, a Vas megyei Múzeumok Értesítője 23(2): 275-295.

Papp, B., Erzberger, P., Ódor, P., Hock, Zs., SzövÉnyi, P., Szurdoki, E. \& Tóth, Z. (2010). Updated checklist and Red List of Hungarian Bryophytes. Studia Botanica Hungarica 41: 31-59.

Pócs, T., Domonkosné-Nagy, É., Pócsné-Gelencsér, I. \& VidA, G. (1958). Vegetationsstundien im Őrség. Budapest, Akadémiai Kiadó, 124 pp.

Pócs, T., van Zanten, B.O. \& Erzberger, P. (2008): Entodon concinnus (De Not.) Paris. In: BlockeEl T. L. (ed.): New national and regional bryophyte records, 18. Journal of Bryology 30: 163. https://doi.org/10.1179/174328208X282463

SzÛ́CS, P. (2009). Mohaflorisztikai vizsgálatok az Őrség területén. (Bryofloristic studies in Őrség region). Praenorica Folia historico-naturalia 11: 13-48.

(submitted: 05.12.2019, accepted: 30.12.2019) 